\title{
Opposition as victimhood in newspaper debates about same-sex marriage
}

For Discourse \& Society journal

\section{Authors:}

Georgina Turner, University of Liverpool, UK

Sara Mills, Sheffield Hallam University, UK

Isabelle van der Bom, Sheffield Hallam University, UK (corresponding author)

Laura Coffey-Glover, Nottingham Trent University, UK

Laura. L. Paterson, Lancaster University, UK

Lucy Jones, University of Nottingham, UK

\section{Corresponding author details:}

Postal address for correspondence, proofs and offprints:

Isabelle van der Bom,

School of English, Owen floor 11,

Sheffield Hallam University

Sheffield S1 1WB

United Kingdom

Institutional email: i.v.bom@shu.ac.uk

Private email: isabelle.vanderbom@gmail.com

Telephone number: +44(0) 1142253599

\section{Short title:}

Opposition as victimhood

\section{Size of paper:}

8502 words (including footnotes, tables, examples \& references)

$132 \mathrm{~KB}(135,680$ bytes $) / 136 \mathrm{~KB}(139,264$ bytes $)$ on disk

\section{Autobiographical note:}

The authors are all discourse analysts with an interest in gender and/or sexuality. All belong to the Discourses of Marriage Research Group (DoM). The group was set up in 2012 with the intention of conducting critical analysis into discourses produced in the media and in public regarding the (then proposed) introduction of legal marriage between same-sex couples by the British government. Thus far, the DoM group has published on implicit homophobia in a British radio debate on same-sex marriage (in Journal of Language and Sexuality), and on survey data concerning surname choices following marriage (in Gender and Language). 


\title{
Opposition as victimhood in media debates about same-sex marriage
}

\author{
ABSTRACT \\ In this paper, we take a queer linguistics approach to the analysis of data from British \\ newspaper articles which discuss the introduction of same-sex marriage. Drawing on \\ methods from CDA and corpus linguistics, we focus on the construction of agency in \\ relation to the government extending marriage to same-sex couples, and those resisting \\ this. We show that opponents to same-sex marriage are represented and represent \\ themselves as victims whose moral values, traditions, and civil liberties are being \\ threatened by the state. Specifically, we argue that victimhood is invoked in a way that \\ both enables and permits discourses of implicit homophobia.
}

KEYWORDS: homophobia; queer linguistics; same-sex marriage; victimhood; agency

\section{INTRODUCTION}

This paper analyses a corpus of British newspaper articles surrounding the UK debate on same-sex marriage. By combining corpus methods with discourse analysis, we have selected a subset of articles from a larger corpus to identify salient topics or discourses that lead to a closer, discourse-level analysis of our topic. We argue that many of the articles, or speakers cited within those articles, represented the groups and individuals who opposed the introduction of same-sex marriage as victims. We therefore focus here on the construction of agency in same-sex marriage debates, and how this facilitates implicitly homophobic discourse. Below, we begin by discussing queer linguistics in relation to the analysis of same-sex marriage debates, before turning to a specific 
discussion of agency and victimhood. We then introduce our corpus and explain our methodology, before presenting our findings and analysis.

\section{LITERATURE REVIEW}

\subsection{Queer linguistics and homophobia}

A queer approach to sociolinguistics (or 'queer linguistics') draws on queer theory what Whittle (1996: 202) describes as an attempt to deconstruct and challenge 'the hegemonic centrism of heterosexism'. In this sense, queer linguistics aims to expose and critique underlying 'heteronormative' ideologies in discourse - those which privilege heterosexuality and gender normative behaviour, and position as deviant those groups or practices that are non-normative - drawing on poststructuralist theory to

reveal and problematise heteronormative discourses (Motschenbacher, 2011). Heteronormativity is closely allied with or leads to homophobia, due to its positioning of non-heterosexuality as other; this may be explicit, as in Pascoe's (2005) investigation of the slur 'fag' as used in American high schools, but it may also be covert, with the overarching message of a text - rather than individual phrases - implicitly referencing heteronormative ideals (Morrish, 2010).

Peterson (2010), for example, finds a covert form of homophobia in his analysis of discourse used by the Family Research Council, a Christian organisation in the USA. He argues that the organisation avoids explicitly homophobic statements through subtle linguistic coding, whereby same-sex couples are positioned as deviant, a stance that is presented as scientific fact. This reflects findings by van der Bom et al. (2015) in their analysis of discourse used on a British radio debate show about the introduction of 
same-sex marriage laws in the UK. They show that opponents of same-sex marriage rarely draw on explicitly religious or moralistic arguments. Instead, stances taken against same-sex marriage are characterised as if they are scientific or legalistic arguments, allowing opponents to present themselves as rational and logical persona whilst also expressing concerns 'that same-sex marriage could lead to the end of western civilisation' (van der Bom et al., 2015: 133).

As LGBT-rights discourse has grown in visibility in a number of countries around the world, opportunities have arisen for those in the public eye to reject or support the introduction of laws that improve same-sex civil rights. In countries such as the UK and USA, intolerance towards minority groups has become less acceptable in recent years (; Brickell, 2001; Brown, 2006). Linguistic analyses of such discourse contexts, such as Peterson's and van der Bom et al's studies, have revealed the drive to avoid explicitly homophobic statements. For example, Burridge (2004) analyses political debate in the UK surrounding the repeal of Section 28, a law that criminalised the 'promotion' of homosexuality to children in the late 1980s. He found that politicians who were in favour of the law avoided explicit homophobia by not referring directly to gay people, instead framing their stances in terms of concern for social welfare.

Love and Baker (2015) compared UK parliamentary debates on the age of consent from 1998-2000 with those on the introduction of same-sex marriage from 2013. They found that while those in opposition to reforming the age of consent for gay couples constructed homosexuality as unnatural, anti-same-sex marriage speakers were more likely to construct homophobic stances in more implicit ways, for example by arguing 
that same-sex marriage would constitute a redefinition of marriage and that allowing same-sex marriage would contravene religious freedoms. These arguments are underpinned by the fear that 'by creating equality for a minority, discrimination will be created for the majority' (2015: 21). In other words, these arguments frame the 'majority' as victims of equality legislation. Baker and Love make the point that while it might be difficult to categorise these arguments against same-sex marriage as explicit forms of 'hate speech', they are implicitly homophobic because they work to exclude LGBT groups. In a related study, Findlay (2014) found that opponents of same-sex marriage framed their stances not against progress, but against change with unknown and potentially dangerous consequences. Similarly, Baunach (2011) found that those arguing against same-sex marriage in the US press tended to frame their argument as a moral issue rather than a civil rights issue: it is difficult to argue against human rights but rational to argue for the protection of 'morality'. To be taken seriously and to be convincing, then, it is important for opponents of same-sex equality to be viewed as rational and concerned about social welfare, rather than bigoted and prejudiced against LGBT people.

In the current study, we build on research already carried out by the Discourses of Marriage research group ${ }^{\mathrm{i}}$ (van der Bom et al. 2015; Jones et al. 2017), by critically investigating (from a queer linguistics perspective) media discourses (specifically, a corpus of newspapers) surrounding the introduction of same-sex marriage to England and Wales in 2014. The Marriage (Same-Sex Couples) Act was introduced following a public consultation by the Conservative Party in 2012, where a small majority of respondents to a government survey voted in favour of equal marriage rights for those 
in same-sex relationships. This prompted debates in the House of Commons and the House of Lords, which in turn led to passionate discussion and argument within the British media as to whether a new Bill should be passed. Part of this process involved lengthy negotiation with religious groups and, in the end, the Bill proposed extending civil marriages to same-sex couples but explicitly ruled out religiously-ordained unions. The Bill was eventually passed, but representatives of religious groups in favour of same-sex marriage (such as the Quakers) argued that it did not bring true equality if gay and lesbian people of faith could not be married - as their heterosexual peers could - in a house of worship. Those who most vocally rejected the Bill, such as those representing the Catholic Church, argued that there were loopholes and inconsistencies in the agreement, and that there was a danger that same-sex couples would eventually be able to marry in a religious ceremony. Our analysis of newspaper discourse considers how such groups voiced their opposition to same-sex marriage, whilst mostly avoiding explicitly homophobic stances, during the time of these debates.

In taking a queer approach, here, it is our aim to foreground the covertly homophobic messages which underlie opposition towards same-sex marriage in our corpus of newspaper texts. We highlight the normalised, naturalised assumptions of sexuality which are relied upon in order to make a compelling case against same-sex marriage, such as through the positioning of that which is 'not traditional' as a threat to a number of potential 'victims'. In this sense, our approach is queer, focused as it is on the 'critique of heteronormativity and gender binarism' (Hall, 2013: 635). On the other hand, queer theory may also be used to reject not only discourses which are against same-sex marriage, but same-sex marriage itself; it has been argued that gay culture has 
become depoliticised in recent years due to a political focus on 'homonormativity', whereby homosexuality is seen as validated by the mainstream, so long as it falls in line with state-sanctioned ideologies (Duggan, 2003). In this sense, when LGB people engage in marriage - the institutional confirmation of a couple's legitimacy - this may be seen as a form of assimilation in line with heteronormative ideals. Indeed, the fact that it was the Conservative government that introduced the Marriage (Same-Sex Couples) Act may support this perspective; given the largely traditional and conventional ideologies of the Tory party, it may be argued that the Act was an effort to regulate and sanitise same-sex relationships ${ }^{\text {ii }}$.

Our approach here does not, however, problematise same-sex marriage itself. Instead, we argue that the introduction of same-sex marriage - enshrined as it now is in the law is a significant step towards equality and thus worthy of celebration. Hall argues that the positioning of practices like same-sex marriage as 'the appropriation of heterosexual normativity' is problematic, because it relies on a supposedly static and stable identity ('heterosexual') to compare to non-heteronormative identities (2013: 637). Heteronormativity is not stable, but instead has and will continue to change; marriage, for example, can no longer be a fundamentally heterosexual institution if it is also available to same-sex couples. Though it is certainly normative, what is 'normal' is itself being changed by political and cultural developments whereby LGBT people are moving towards equality (Hall, 2013: 639). In this paper, then, we take a liberationist stance in defending and promoting the introduction of same-sex marriage, whilst also taking a queer theoretical approach to critically analyse the heteronormative discourse 
used to argue against it. As we go on to show, this discourse is founded on the production of a victim/agent binary.

\subsection{Victimhood and agency}

The issue of agency and victimhood, the focus of the current study, has long been central to those engaging in critical analysis. For example, second wave feminists exploring the relationship between language and gender in the 1970s and 80s expressed concern with the way that women were linguistically represented as victims of patriarchal demands (Lakoff, 1973; Spender, 1980). Indeed, the ability to determine one's own fate as a woman drove many of the political debates from the 1960s onwards, in relation to a range of different campaigns around a woman's right to choose.

However, victimhood was often criticised by feminists who wanted not simply to be seen as responsive to male oppression, leading to a shift from a focus on women's victimhood to a focus on women's agency and, ultimately, a more productive form of activism. A similar shift took place in relation to gay and lesbian rights post-Stonewall, when queer subjects were encouraged through activism to 'come out' in order to gain agency and change perceptions of homosexual deviancy (Plummer, 1995). For queer theorists such as Butler (1999), indeed, agency is created within discourse rather than being a predetermined disposition possessed or claimed as such by the individual. Thus, one is positioned by discourses, and one positions oneself in relation to those discourses. In this sense, agency entails not only the passive positions that people are allocated, or that they actively take up, but also the stances that they strategically create 
for themselves. For example, individuals may cast themselves as victims in order to accrue the benefits and/or sympathy that they consider to be due.

Agency has also been a focus of attention for critical discourse analysts, with issues of transitivity (who does what to whom) forming the backbone to many analyses (see, for example, Fairclough, 1992; van Dijk, 1998; Wodak et al., 2001). Critical discourse analysis (CDA) analyses the way texts (such as newspapers) represent individuals or groups; people may be referred to using the passive voice or nominalisation, for example, which might characterise them as victims and as acted-upon. Early CDA was thus focused on victimhood as a useful political strategy, yet, as we will show here, the representation of agency is highly complex, and involves more than passive constructions and transitivity. In taking a queer linguistics perspective, we are concerned with how victimhood is invoked in a way which both enables and permits discourses of homophobia: below, we show how those who make oppositional statements about same-sex marriage often position themselves as wronged and deserving of sympathy, rather than as aggressors or homophobes.

\section{METHODOLOGY}

To analyse media representations of same-sex marriage debates, we used Nexis UK to compile a corpus of UK national newspaper texts spanning from the government's announcement of the same-sex marriage consultation in September 2011 to the occurrence of the first same-sex marriages in April 2013. We searched Nexis UK for the terms <"Marriage" (major mentions) AND "same sex" OR "gay" OR "homosexual" OR "civil partnership"> occurring in national UK newspapers and then manually 
analysed our search results to eliminate texts focusing on same-sex marriage in other countries, duplicate entries, and other erroneous hits. The corpus contains 2599 texts discussing same-sex marriage in the UK (primarily England and Wales as Scottish same-sex marriage debates followed a slightly different timeline). It comprises $1,327,817$ words and texts come from a range of publications, including the Independent, Telegraph, Guardian, Daily Mail, Daily Mirror, The Times, Daily Express, and the Morning Star. There are four different text types: blogs, letters, comment/opinion pieces, and news, the latter of which forms the majority of the corpus (1707 texts). Whilst the corpus contains different sources/text types, the present analysis is not concerned with how these components of the corpus differ. That is, we treat our corpus as a whole and consider it representative of the different elements of same-sex marriage debates in newspaper texts. Furthermore, we do not aim to provide an overview of all discourses drawn upon in debates about same-sex marriage, but rather focus specifically on the nuances of discourses of agency and victimhood. iii

The number of news articles etc. devoted to same-sex marriage over the timespan of the corpus is indicative of public interest and the apparent newsworthiness of same-sex marriage debates. Indeed, same-sex marriage legislation is frequently referred to as controversial and/or divisive in our corpus (see section 4), suggesting that the topic is linked to conflict and contrasting stances, which make it newsworthy. Such labelling, combined with the number of articles, also suggests that newspaper texts were a prominent site for debate and justifies our decision to focus on such texts in the present analysis (instead of other media texts such as radio or television debates). Press guidelines dictate that newspapers cannot discriminate based on sexuality (c.f. Baker, 
2014) and thus, it was not expected such conflict would be expressed in terms of explicit homophobia. However, whilst we assumed direct prejudice was unlikely to occur, we expected to find evidence of implicit homophobic discourse (van der Bom et al., 2015).

In order to focus our analysis, we chose to begin by selecting a subset of our corpus for close reading, using corpus software package ProtAnt (Anthony and Baker, 2015a). ProtAnt generates a list of the most prototypical texts in a corpus by comparing the corpus under analysis to a reference corpus and ranking texts in order of the number of keywords they contain (Anthony and Baker, 2015b: 278) ${ }^{\mathrm{iv}}$. We used our whole corpus as the reference corpus and compared it with month-long subsets of texts. This meant we could calculate which keywords (and topics) were important in any given month, in comparison to wider debates about same-sex marriage in the UK. ${ }^{v}$ Controlling for publication source and volume of texts per month, we used ProtAnt to select 20 texts for close reading which were distributed between the authors. ${ }^{\text {vi }}$ ProtAnt was a suitable tool for text selection because a) it reduced the subjective bias associated with manual text selection, meaning we were not cherry-picking, b) it meant that we focused our close reading on texts exhibiting characteristics representative of the wider corpus, and thus, our analysis was not skewed by outlier texts, and c) it facilitated a systematic sampling of texts across the span of the corpus.

We initially worked independently on our analyses before meeting to discuss our findings, when it became clear that claiming victimhood (explicitly or implicitly) for those opposing same-sex marriage was a key characteristic running throughout the 
articles analysed. We established the following two hypotheses based on our initial analysis: firstly, those opposing same-sex marriage on religious grounds would feature in discourses of victimhood; secondly, in line with previous research (discussed above), opponents of same-sex marriage would not appear to be explicitly homophobic, but would be situated within same-sex marriage debates as protecting the (heteronormative) status quo. In order to test these hypotheses, we each reanalysed our texts and selected four to five ideologically salient terms for further investigation. Table 1 includes a list of all our corpus queries, based on our ideologically salient words. For example, *allow* searches the corpus for all instances of allow (our ideologically salient term) but also includes in the query hits related terms, such as allowing, disallow, etc.

Table 1: List of ideologically salient search terms

\begin{tabular}{|l|l|l|}
\hline Search term & No. of hits (whole corpus) & $\begin{array}{l}\text { No. of lines analysed } \\
(\min 50, \text { max 200) }\end{array}$ \\
\hline *allow*vii & 2128 & 200 \\
\hline appal* & 58 & 50 \\
\hline compel* $^{*}$ & 109 & 55 \\
\hline conscienc* $^{*}$ & 380 & 190 \\
\hline consult* & 1130 & 200 \\
\hline$*$ controver* & 319 & 160 \\
\hline defend* & 220 & 110 \\
\hline demand* & 307 & 154 \\
\hline exclude & 142 & 71 \\
\hline ffamily & 1280 & 200 \\
\hline forc* & 1145 & 200 \\
\hline
\end{tabular}




\begin{tabular}{|l|l|l|}
\hline influence* & 105 & 53 \\
\hline$\{$ let $\}$ & 367 & 184 \\
\hline opposi* & 1211 & 200 \\
\hline ordinar* & 130 & 65 \\
\hline overrul* & 23 & 12 \\
\hline *protect* & 751 & 200 \\
\hline push_through & 74 & 50 \\
\hline shock* & 123 & 62 \\
\hline *valu* & 447 & 200 \\
\hline warn* & 895 & 200 \\
\hline TOTAL & $\mathbf{1 1 3 3 4}$ & $\mathbf{2 8 1 6}$ \\
\hline
\end{tabular}

We took the decision to focus on ideologically salient terms because we were not satisfied that bald statistical significance would take us towards what appeared qualitatively to be important when we each (manually) examined the prototypical news articles: a discourse of victimhood that prevailed across publications. Discourses of victimhood can be expressed in multiple ways and single lexemes may not repeat often enough to reach statistical significance. Nevertheless, it is the cumulative effect of different lexical items (and how they are used in wider discourses) that result in constructions of victimhood. Although our method differs from traditional corpus analyses, which tend to begin with keywords or collocates, we endorse Bachmann's (2011: 101) assertion that keyword analysis as a method of highlighting discourses 'has its limits', partly because keyword lists do 'not group semantically similar words automatically, since only word forms are counted'. In his own analysis of civil partnership debates, Bachmann argues that 'equality is not a keyword' in the corpus 
sense, but rather "the semantic field of "equality" is highly frequent and would be a "key semantic field" (Bachmann, 2011: 101). However, we also follow Love and Baker (2015) in adopting a combination of corpus-driven (using frequency information to identify saliency) ${ }^{\text {viii }}$ and corpus-based (examining words or patterns deemed to be of relevance) approaches. In their work on homophobic discourses in same-sex marriage debates, Love and Baker calculate keywords but also select words for analysis based on their perceived relevance; we mirror their assertion that this dual focus results in 'a more thorough analysis' (2015: 8).

Concordance lines ${ }^{\mathrm{ix}}$ for each of our search terms were generated based on the whole corpus using WordSmith Tools (Scott, 2012) and distributed amongst the authors for systematic, close analysis. The queries for the 21 ideologically salient search terms returned 11,344 hits, the manual analysis of which would have been infeasible. To make the dataset more manageable, we thinned the concordance lines, deciding to look at $50 \%$ of the hits for each term (but analysing 200 maximum and 50 minimum per search term - see Table 1). For example, we took $50 \%$ of the hits for compel* (55 hits), 200 hits for *allow*, as this was enough to see the types of patterns occurring in the data, and 50 hits for terms like appal*, where $50 \%$ of hits was a very small number. Below, we present examples from articles in our corpus which illustrate the use of ideologically salient terms (Table 1), along with our analysis of the ways in which this language use contributed to implicitly homophobic discourse regarding same-sex marriage via representation of its opponents.

\section{ANALYSIS}


In our data, the same-sex marriage Bill is frequently described as being 'controversial', a word that indicates both significance and also potential disagreement or tension, and could suggest implicit opposition to the issue at hand. Indeed, the Guardian style guide notes that the term is 'overused, typically to show that the writer disapproves of something' (Guardian, 2016). In the present corpus, 107 of 185 hits of controversial $(57.84 \%)$ co-occur with legislation, plans, Bill, and changes, and issue. Furthermore, 'controversial comments' (see example 3, below) occurs when newspapers refer to the speech of those opposed to the legislation:

1) The first gay weddings are set to take place in England and Wales in the summer of 2014, after controversial legislation to introduce samesex marriage (The Daily Telegraph, 17/07/13)

2) MPs are expected to debate the controversial Bill next month. (Mail Online, 26/01/13)

3) Euro-MP Nigel Farage responded to our investigation by condemning Dr Gasper's "unacceptable war" against homosexuals. She was among a number of UKIP members who posted controversial comments [...] (Daily Mirror, 20/01/13)

However, closer analysis of the frequency of controversial (and its synonyms; see Table 2, below) in our corpus and in large corpora of the Guardian and the Daily Mail ${ }^{\mathrm{x}}$ indicates that controversial seems to be a popular term for issues that include some level of public discussion or debate. Thus, same-sex marriage debates may be no more controversial than other debates. However, the term 'divisive' is used more frequently 
than expected in comparison to its general use in the Guardian and Daily Mail (consider the normalised frequencies of words per million in Table 2) suggesting that, more than being controversial - a term relating to 'public disagreement' (OED, 2015) same-sex marriage debates actively create social division. Indeed, the Bill is described as 'divisive' and 'legally flawed', 'unnecessary', 'essentially ideological', 'destructive', and 'ill thought through and constitutionally wrong'.

Table 2: The use of 'controversial' and its synonyms

\begin{tabular}{|l|l|l|l|l|l|l|l|}
\hline & \multicolumn{2}{|c|}{ Our corpus } & \multicolumn{2}{c|}{ Guardian } & \multicolumn{2}{c|}{ Daily Mail } \\
\hline & Freq. & $\begin{array}{l}\text { Per } \\
\text { million } \\
\text { words }\end{array}$ & Freq. & $\begin{array}{l}\text { Per } \\
\text { million } \\
\text { words }\end{array}$ & Freq. & $\begin{array}{l}\text { Per million } \\
\text { words }\end{array}$ \\
\hline controversial & 185 & 140.51 & 2843 & 50.40 & 25077 & 77.23 \\
\hline & \multicolumn{5}{|l|}{} \\
\hline divisive & 92 & 69.88 & 725 & 12.85 & 1 & 0.00 \\
\hline contentious & 48 & 36.47 & 514 & 9.11 & 1329 & 4.09 \\
\hline heated & 24 & 18.22 & 332 & 5.89 & 4026 & 12.40 \\
\hline notorious & 19 & 14.43 & 844 & 14.96 & 10203 & 31.42 \\
\hline provocative & 7 & 5.32 & 320 & 5.67 & 1932 & 5.95 \\
\hline scandalous & 6 & 4.56 & 256 & 4.54 & 922 & 2.84 \\
\hline debatable & 3 & 2.28 & 101 & 1.79 & 109 & 0.34 \\
\hline polemic & 2 & 1.52 & 57 & 1.01 & 32 & 0.10 \\
\hline
\end{tabular}

Similarly, the use of 'fight' (222 hits) to describe the debates about same-sex marriage legislation also functions as a framing device, reinforcing a polar distinction between those who are for same-sex marriage and those who are against it. Many of the 
references to 'fight' involve religious leaders challenging the government with a view to 'saving' marriage (see examples 4 and 5, below). Moreover the government, and the then-Prime Minister David Cameron, are the ones accused of 'picking the fight' (example 6). The term 'fight on' occurs 11 times - twice as a direct quotation from the Coalition for Marriage - is also used to describe the actions of those opposed to samesex marriage. ${ }^{\mathrm{xi}}$ We therefore have the (sometimes implicit) positioning of the antimarriage-equality campaigners as merely responding to an act of (ideological) aggression by those who want equal marriage rights:

4) The fight is getting dirty. In one corner we have the Coalition for Marriage, launched with some considerable fanfare in February by an umbrella of organisations and individuals that oppose any plans to redefine "traditional" marriage. [...] In the opposite corner we have the Equalities Minister, Lynne Featherstone, with the official Government line that it's a matter of how to introduce full gay marriage, not if. (The Independent, 07/04/12)

5) Similarly, there was no great public campaign that forced the Government's hand. No, this was a fight that the Prime Minister chose to pick. (The Telegraph, 03/02/13)

Example 4, which comes from the left-wing press and is ultimately sympathetic to same-sex marriage legislation, contextualises the verbal debate about same-sex marriage as a boxing match through the use of a 'fight' metaphor as well as the spatial metaphors 'in one corner' and 'in the opposite corner'. Here, debates about same-sex 
marriage move from the conceptual/verbal domain towards language associated with (orchestrated) physical violence. The corpus also contains reports from The Sunday Times that the 'Tory MP leading a campaign against gay marriage' received 'death threats', and 'hate mail'. Those opposing equal marriage are critical of the 'fight' that 'ordinary people' are being drawn into 'unnecessarily'. Such talk is worth breaking down: not only is there an implicit level of heroism imbued in the positions of those opposed to - or resisting - same-sex marriage, but there is also rhetorical weight in the use of 'ordinary people' to refer (and appeal) to the voting public:

6) Bob Woollard, said: 'This dilution and unravelling of marriage has demotivated many ordinary loyal Conservative Party members $[\ldots]$ (Daily Mail, 18/05/13)

7) "Ordinary people want him to stop meddling with the institution of marriage and get on with fixing Britain's flatlining economy."(The Telegraph, 08/01/13)

8) A Scotland for Marriage spokesman said: "The extent of national opposition to redefining marriage is becoming apparent. Ordinary men and women do not want to see the destruction of the concept in law of mother and father [...] (The Telegraph, 03/02/13)

When we look at the use of 'ordinary' we can see that it not only indicates a break between the leadership of the Conservative Party and its members, as in example 6 note also the construction of the Bill as destroying marriage, activating a sense of heroic resistance, or distance between the political elite and the public, as illustrated by 
example 7 - here, meddling suggests that, unlike the economy, marriage is not an affair for government. It also distinguishes those in same-sex relationships as extraordinary; in example 8 - the pairing of men and women, and the introduction of parenthood, are devices that reinforce the notion that 'ordinary' is synonymous with 'heterosexual'.

While we could have devoted an entire paper to thinking about the premising of the arguments presented against equal marriage legislation, what we have found is that it is largely in line with what was found in contemporaneous broadcast debates (van der Bom et al., 2015). We find, in this corpus, the same concerns about the devaluation of marriage as an institution, and the same penchant for danger metaphors to conjure up an imaginary, yet inevitable, bad future:

9) Legalising same-sex marriage will pose a threat to the freedoms of teachers with traditionalist views, a Conservative MP has warned. David Burrowes said classrooms would be subjected to a "new state orthodoxy' in which teachers who opposed homosexual weddings would be forced to remain silent for fear of being sacked. (The Telegraph, 16/01/13)

10) Parent campaigners against the coalition government's plans warn it will put classrooms on the frontline of a political correctness war and parents who object to the teaching of same-sex marriage could be classed as bigots. (Sunday Express, 26/02/12) 
11) Mr Cameron's chickens are coming home to roost and it will be ordinary people with a religious belief who yet again fall victim to the totalitarian forces of political correctness. (Mail Online, 02/08/13)

The euphemistic nature of 'traditionalist views' and the potential threat to children that same-sex marriage brings, shown in example 9, are typical of the discourse found by van der Bom et al. Similarly, the invocation of 'political correctness' (shown in examples 10 and 11) is a typical tactic of this sort of discourse, tied as it is to the denigration of progressive politics as empty rhetoric (Johnson et al., 2003). Returning to the central focus of this article, it is evident from example 11 that opponents of equal marriage rights are explicitly rendered victims in our corpus. These excerpts illustrate the state of abjection into which opponents are apparently cast by the change in the law - note that in addition to being ordinary people, they are parents and teachers, a referential strategy that marks them as responsible people with relevant and wellmotivated opinions, rather than as political activists. In addition to the semantic prosody of 'state orthodoxy' in example 9 - evocative of negatively evaluated political regimes such as China and the USSR and thus the inhibition of individual freedoms, and 'totalitarian forces' (example 11) - the constructed powerlessness of the opponents, such as teachers forced to silence their opposition, is underlined by the epistemic certainty of these constructions when foreshadowing the impact of the Bill: will pose, would be, it will. Our corpus analysis shows that modal auxiliaries constitute a key set in these texts, with 'will' featuring as a statistically significant $(\mathrm{p}<0.0001)$ term. 
Similarly, the prevalence of 'warn' (895 hits including warning/s and warned), in proximity to terms such as 'dangers' and 'force ${ }^{\text {'xii }}$, relies on the assumption that those doing the warning have a clear vision of the future, yet are being denied opportunities to avert it by the dogmatic commitment to equality that their opponents demonstrate:

12) What will be the fate for teachers who [...] are not prepared to condone gay marriage or for parents who object to their children being given such teaching? It is hypocritical for supporters of gay marriage to demand rights for themselves they are not willing to give others (our emphasis). (Guardian, 14/012/12)

Example 12, which is a letter to the editor, is an instance of the inclusion of a right-wing perspective in a left-wing newspaper. It demonstrates that those both for and against same-sex marriage make use of terms such as 'demand', which frame their opponents' goals as being taken by force, and both claim to be 'appalled' by what the other is arguing. There is a pool of terms, however, from which those opposing equal marriage rights more typically draw. We must keep in mind the prominence of a set of key players whose quotes circulate repeatedly in these news texts. Comments from the former Archbishop of Canterbury George Carey, for instance, might operate as a precis of religious objections. However, collectively, these terms entrench a sense of assault as opposed to debate.

Despite polling across the country showing public support for equal marriage rights, the descriptions of the move towards equal marriage that we are examining here construct 
equal marriage as something being enforced against the will of 'the people'. Philip Hammond (Conservative MP and Defence Secretary at the time) is directly quoted as saying 'There was no huge demand for this [same-sex marriage]'. This phrase is repeated as direct quotation 7 times in the corpus, but is also used twice in indirect quotations and alongside 7 occurrences of the paraphrased 'no great demand'. The use of these two phrases demonstrates that repeated excerpts from the corpus cannot be explained merely as repeated quotations, but rather the repetition of 'no huge demand' and 'no great demand' demonstrates how arguments are detached somewhat from their speakers and become part of wider debates about same-sex marriage. In opposition to this perceived lack of 'demand' victimhood is constructed through the use of terms such as 'pushed through' in relation to the legislation, and 'forced' and 'compelled' in relation to the effects of the legislation on, in particular, religious groups. These terms position religious groups as being subjected to external and unjust pressure. The repetitive use of 'push through' and its synonyms invites readers to view the process of legalising same-sex marriage as undemocratic - instead of the 'victims' being (largely) right-wing MPs, it is democracy itself that is at stake. A notable example is a letter by Conservative MPs to the Prime Minister, published in the Telegraph:

13) We are of the clear view that there is no mandate for this Bill to be passed in either the 2010 Conservative Manifesto or the 2010 Coalition Agreement and that it is being pushed through Parliament in a manner which a significant proportion of Conservative Party members find extremely distasteful and contrary to the principles of 
both the Party and the best traditions of our democracy (The Telegraph, 03/02/13).

The idea that the move is without mandate is patently untrue, the Conservatives produced a pre-election campaign in 2010 which included a 'contract for equalities', but it perhaps holds an appeal that more explicitly homophobic discourses lack. The use of 'push through' refers to certain groups, mainly David Cameron and liberal Conservatives, who are represented as forcibly imposing this legislation against the wishes of members. The description of what exactly is being pushed through varies from the more positive ('reforms' and 'equal marriage'), through the neutral ('legislation', 'changes', 'bill', 'vote' and 'laws legalising same-sex marriage'), to the more negative ('controversial proposals', 'gay marriage law', 'reactionary policies' and 'sham consultation'). In our sample, the victims of something having been 'pushed through' are either: the public, because it goes against their opinion; the church or other religious bodies, because it goes against their beliefs; the Conservative party, because they fear they will lose voters and/or disagree with David Cameron; or democracy, because freedom of expression is being threatened.

This theme is echoed in the use of terms referring to bullying; the term 'bully' is used to characterise gay rights groups such as Stonewall, which is also described as a 'gay pressure group'; elsewhere there are references to 'secular attack'. In turn this is amplified by arguments that focus on the likelihood that religious organisations and their representatives, as well as those in the public sector such as teachers, will be 'forced'/'compelled' to recognise same-sex marriages: 
14) It would spark legal challenges in the European Court of Human Rights by gay rights campaigners, which would force churches to conduct religious same-sex marriage against their will (Independent, 03/07/12).

15) Catholic leaders claim churches could be sued for refusing to conduct gay marriage ceremonies, even though the proposals would not force them to. They also warned that teachers could face action if they refuse to educate kids about equal marriage. (The Sun, 18/07/12)

16) Religious organisations would not be compelled to conduct same-sex marriages in their places of worship. However, the Church of England and other religious bodies have criticised the impact of the plans on the institution of marriage as a whole. (The Telegraph, 06/010/12)

Besides the fact that they ignore the common-sense recognition that same-sex couples are unlikely to want to be married by a reluctant celebrant, much less a celebrant forced to conduct the ceremony via the courts, the above examples show how opponents of marriage equality are constructed, and most often construct themselves, as being anxious, or even in fear, of the consequences of a change to marriage legislation. There are traces of the kind of metaphorical 'slippery slope' rhetoric previously identified by van der Bom et al. (2015) in these predictions - note, once again, the epistemic certainty (example 14) with which a speaker envisages 'challenges in the European Court of Human Rights', 'which would' be successful. Similarly, fears around security of employment (example 15) appear with some regularity; these appeal to a sense of 
decency - who would knowingly endanger otherwise secure jobs? - that might be especially potent in a post-2008 economy. Examples 17 and 18, below, are demonstrative of the way that these fears can give way to hyperbole via ominous historic references. In this way, the progressive case for extending the definition of marriage is characterised as being potentially regressive:

17) They say that this could effectively exclude Christians who share their beliefs from certain jobs. They even fear that their freedom to preach could be threatened and liken the proposals to Henry VIII's moves to take control of the Church in England, leading to the split with Rome. (The Times, 12/01/13)

18) Their fear is that Catholics who believe in the traditional meaning of marriage would effectively be excluded from some jobs - in the same way as Catholics were barred from many professions from the Reformation until the 19th century. (Mail Online, 12/01/13)

Of course religious exemptions were on the table (as examples 15 and 16 acknowledge), but those exemptions we found routinely to be a source of anxiety in these discussions, with fears about the religious protections making particular reference to the European Court of Human Rights. 'Protection' and related terms appear surrounded by terms such as 'robust'/'robustness', 'adequate', 'ample', 'watertight' and 'durability', which is revealing of the fearfulness with which the protections were discussed. Much as was the case in 'Brexit' campaigning in the build up to the UK's referendum on EU membership in June 2016, these arguments often presuppose that the 
European court would overrule the British government. Opponents of same-sex marriage are constructed as being at the mercy of equality campaigners, with only thin hopes of government protection to cling to. What we also see in example 16 , above, is a shift from concerns about the impact of the proposals on religious organisations and their employees and congregations to 'the impact [...] on the institution of marriage as a whole'. This shift was not uncommon, and often serves to characterise those supporting the move towards equal marriage rights as aggressors.

In the following examples we see metaphorical constructions suggestive of violence (in each we have italicised the key words). Examples 19-21 demonstrate that both the leftand right-wing press include direct quotations from people who oppose same-sex marriage.

19) SIR - If the meaning of marriage is to be hijacked, then the time has come to distinguish between the civil contract of marriage and the church ceremony of holy matrimony. (The Telegraph, 17/12/12)

20) Cardinal O'Brien suggested that the Scottish Government was redefining the term "marriage" on a whim $[\ldots]$ He went on : [...] "This proposal represents a grotesque subversion of a universally accepted human right." (The Times, 12/09/11)

21) Lord Carey described plans to introduce same-sex marriage as a "hostile strike" and an act of "cultural and theological vandalism" against an institution dating back thousands of years. (The Independent, 12/02/12) 
The semantic contrast between these terms - hijacked, grotesque subversion (with the prefix 'grotesque' giving 'subversion' a carnivalesque quality), vandalism - and their subjects - 'holy matrimony', 'a universally accepted human right', 'an institution dating back thousands of years' - reveals the careful construction of a sense of danger in these texts. While the former terms resonate with discourses of crime and delinquency, the latter appeal to a sense of propriety and heritage; the excerpts therefore encourage the reader to feel moral outrage at the introduction of the Bill.

Similarly, opponents of same-sex marriage were often represented as not only comparatively moral and just, but as having logic and history on their side:

22) So ministers have drawn up "gobbledegook" rules which overrule the dictionary and scrap the centuries-old definitions of male and female spouses. (Mail Online, 28/06/13)

23) Civil servants have overruled the Oxford English Dictionary and hundreds of years of common usage. (The Telegraph, 27/06/13)

In example 22, the speaker conjures an image of the creation of the new, more open definition of marriage as shoddy and man-made, in comparison to the dictionary, which is presented as an apparently 'natural' rule book. In example 23, there is a similar appeal to tradition, this time juxtaposing the authoritative Oxford English Dictionary with mere civil servants; when we consider the prevalence of 'the government' or 'David Cameron' elsewhere, this reference appears to be motivated by the desire to 
disparage those introducing the law, effectively questioning what right they have to do this. Other, similar, arguments refer to the Bible. The link to tradition, whereby marriage between a man and a woman is held up as natural because of its longevity and, at times, its sanctity, is again reflected in work by van der Bom et al. (2015). Of significance here, though, is the agency given to civil servants and ministers in overruling this tradition (who are not entitled to do so), and the implicit lack of agency given to the opponents (who know better).

\section{CONCLUSION}

In this paper, we have taken a queer linguistics approach focused on the discourses surrounding same-sex marriage. Specifically, we have argued that victimhood is invoked in a way that both enables and permits discourses of implicit homophobia. Through our bottom-up approach to our corpus of newspaper texts, we have shown how victimhood is constructed and claimed most often by, and on behalf of, opponents of same-sex marriage. Our analysis demonstrates that those presented as being negatively impacted by the introduction of same-sex marriage are most typically those of a Christian faith (though other faiths were mentioned, Christianity dominated due to its prevalence in the UK). Typically, members of the government are framed as the agents intending to force an unwanted change to the definition of marriage on the victims.

The dominant discourse in our corpus, therefore, was an opposition between religion and the state: the people who are the victims are typically religious groups, or people who are assumed to be religious, such as teachers. This opposition is founded upon the argument that the state does not have the right to change the definition of marriage. As 
a result, by conceptualising marriage as the solely religious practice of holy matrimony, those opposing same-sex marriage perceive its introduction to be an assault on their religious freedoms, insofar as same-sex partnerships are not recognised within their doctrine. The opposing view, endorsed by the government, is seen as elevating sexual equality above religious freedoms, and this is particularly threatening as it constitutes a dichotomy between church and state, whereby the church is denied agency. Significantly, despite opposition from the church, it was the state which had the ultimate power to enshrine same-sex marriage within law.

As well as framing marriage - specifically, a religious definition of marriage - as the victim of the legislation passed in 2012 , the media discourse shown here adds to the construction of a 'David and Goliath' battle in which the opponents of equal marriage despite having God, the dictionary, and tradition on their side, are fending off a large and unyielding adversary (the state). Opponents construct their opposition as motivated not by homophobia but by a desire to protect tradition and religious freedoms from secular institutional change. Protection, or some notion of it, features prominently in this sample, and overwhelmingly in relation to certain groups or institutions being protected from equal marriage legislation. At times these groups or institutions are religious organisations, at others it is marriage itself. In a minority of cases it is not marriage but the rather more biblical 'procreation'. But protection is also argued to be needed for anybody opposing same-sex marriage, as well as more abstract notions such as 'personal morality' and free speech. 
However, marriage is not solely a religious celebration. It is also a secular, legally binding contract which formally recognises the union of two people. Ultimately, it is the state, not the church, that has the power to determine the legitimacy of such a union. The crux of the problem, therefore, seems to be the church and state's differing perceptions of what marriage is. Defining marriage exclusively as 'the union between a man and a woman' delegitimises same-sex unions, and therefore excludes people on the grounds of their sexuality. It is therefore homophobic because it stands in opposition to those in same-sex relationships having the same rights as those in heterosexual relationships.

Despite varying perspectives on same-sex marriage, it still tends to be depicted in one way: as a battle between church and state. Regardless of who the victim is (i.e. marriage, the church, or religious people), there is always a victim and an opposing agent; there is no neutral ground established in such debates. This dichotomy of victim and agent is therefore a key framing device in media discussions of same-sex marriage legislation. Despite the prevalence of this frame, ultimately same-sex marriage legislation was passed, and therefore those in opposition lost.

Ultimately, and independent of the political leanings of individual newspapers, across the British press we have found evidence of homophobic discourse. However, in traditionally left-wing media within our corpus, such examples tend to be representations of the voices of others, such as in letters to the editor (as in example 12), or the quotation of religious leaders (as in example 21). The inclusion of these perspectives facilitates a more balanced debate, rather than representing an overall trend 
in the language used by the left-wing media when discussing same-sex marriage. What this demonstrates, of course, is the important role that newspapers play in reproducing and circulating dominant ideologies, (somewhat) irrespective of the ideological bias held by individual media institutions.

\section{${ }^{\mathrm{i}}$ http://discoursesofmarriage.blogspot.com/}

ii Our thanks to an anonymous reviewer for this observation.

iii An overview of the corpus, its construction, and analysis of changes in discourses surrounding samesex marriage is given in Paterson and Coffey-Glover (in preparation).

${ }^{\text {iv }}$ It is arguable that ProtAnt actually ranks texts in terms of their hypertypicality (i.e. those at the top of the list will likely include more of the corpus keywords than average texts). However, this is not a concern for the present study: the purpose of choosing a subset of texts for close reading was to see how the key elements of same-sex marriage debates were contextualised within wider discourse.

${ }^{v}$ The alternative option - comparing the whole corpus to a reference corpus of UK newspaper texts and establishing the most prototypical articles overall - would not have provided us with a dataset that spanned the range of topics in our corpus, nor could it have shown the nuances of debates occurring at different points in the same-sex marriage timeline.

${ }^{\text {vi }}$ Taking the top 10 prototypical articles per month we then used a random number generator to select articles from these prototypes which matched the overall distribution of the corpus.

vii The asterisk denotes 'none or more characters' so the corpus query *allow* would return forms including allow, allowing, disallow, disallowed, etc. The curled brackets - \{\} - denote lemma searches, so \{family\} will return family, families, etc.

viii The use of corpus software amplifies what Carney (1972) described as 'the serendipity effect' of content analysis (the discovery of something unexpected or less visible to the reader of a body of texts). In this case, this enabled us to identify that 'allow', for example, appeared in the corpus alongside terms such as 'let', 'hinder*' and 'help*' as part of a key - statistically significant $(\mathrm{p}<0.0001)$ - semantic domain. 
${ }^{\text {ix }}$ Concordance lines are all hits of a corpus query presented within their immediate context (usually ten words either side, but in this case the concordance lines were expanded to facilitate wider discourse analysis).

${ }^{x}$ These corpora, which contain all the news and debate articles from both sources published between 2010 and 2016, are held at Lancaster University and were compiled, in the first instance, for work on poverty discourses (see Paterson and Gregory forthcoming).

${ }^{x i}$ It is also worth noting that the direct quotation 'Stonewall will fight on' also occurs twice in the corpus, suggesting that the term was also used by those in favour of same-sex marriage.

xii Warn, warns, warning, and warned, as well as forced, are statistically significant keywords in our corpus.

\section{REFERENCES}

Anthony L, Baker P (2015a) ProtAnt (version 1.0). [Computer software]. Tokyo:

Waseda University., http:Ilwww.lawrenceanthony.net/software/antconc/

Anthony L, Baker P (2015b) ProtAnt: A tool for analysing the prototypicality of texts. International Journal of Corpus Linguistics 20(3): 273-292.

van der Bom I, Coffey-Glover L, Jones L, Mills S, Paterson LL (2015) Implicit homophobic argument structure: Equal marriage discourse in the Moral Maze Journal of Language and Sexuality 4(1): 102-137.

Bachmann I (2011) Civil partnership - 'gay marriage in all but name': A corpus-driven analysis of discourses of same-sex relationships in the UK parliament. Corpora 6(1): 77-105.

Baker P (2014) In: Wei LFJ (ed.) Discourse in Context: Contemporary Applied Linguistics Volume 3. New York: Bloomsbury. pp 27-48. 
Baunach, D M (2011) Decomposing trends in attitudes toward gay marriage, 19882006. Social Science Quarterly 92(2): 346-363.

Brickell C (2001) Whose "special treatment"? Heterosexism and the problems with liberalism. Sexualities 4(2): 211-236.

Brown W (2006) Regulating aversion: Tolerance in the age of identity and empire. Oxford: Princeton University Press.

Burridge J (2004) “I am not homophobic but...”: disclaiming in discourse resisting repeal of Section 28. Sexualities 7(3): 327-344.

Butler J (1999) Gender Trouble. London: Routledge.

Carney TF (1972) Content analysis: A technique for systematic inference from communications. Winnipeg, MB: University of Manitoba Press.

Duggan L (2003) The Twilight of Equality? Neoliberalism, Cultural Politics, and the Attack on Democracy. Boston: Beacon Press.

Fairclough N (1992) Discourse and Social Change. Cambridge: Polity Press.

Findlay J (2014) Unnatural acts lead to unconsummated marriages: Discourses of homosexuality within the House of Lords revisited. Paper presented at the 8th International Gender and Language Association Conference, Vancouver, Canada.

Guardian. (2016) Guardian and Observer style guide.

<https://www.theguardian.com/guardian-observer-style-guide-c >. Accessed 18 Aug 2016.

Hall K (2013) It's a hijra'! Queer Linguistics Revisited. Discourse and Society 24(5): 634-642. 
Johnson S, Culpeper J, Suhr S (2003) From "politically correct councillors" to "Blairite nonsense": discourses of "political correctness" in three British newspapers. Discourse \& Society 14(1): 29-47.

Jones L, Mills S, Paterson LL, Turner G, Coffey-Glover L (2017) Identity and naming practices in marriage and civil partnerships. Gender and Language 11(3): to appear.

Lakoff R (1973) Language and woman's place. Language in Society 2(1): 45-80.

Love R, Baker P (2015) The hate that dare not speak its name?. Journal of Language, Aggression and Conflict 3(1): 57-86.

Morrish E (2010) 'Situating and resisting homophobic discourse: Response to Leap, Junge, Peterson, and Provencher'. Gender and Language 4(2): 323-335.

Pascoe CJ (2005) “Dude, You're a Fag”: Adolescent Masculinity and the Fag Discourse. Sexualities 8(3): 329-346.

Paterson LL, Coffey-Glover L (in preparation) Tracing discourses of marriage across same-sex marriage debates in the UK press 2011-2014.

Paterson LL, Gregory I (forthcoming) Discourse of Poverty and Place. London: Palgrave.

Peterson D (2010) “The basis for a free, just and stable society": Institutional homophobia and governance at the Family Research Council. Gender and Language 4(2): 257-286.

Plummer K (1995) Telling sexual stories: Power, change and social worlds. London: Routledge.

OED. 2015. Entry for 'controversial'. <www.oed.com>. Accessed 18 August 2016. 
Motschenbacher H(2011) Taking Queer Linguistics further: Sociolinguistics and critical heteronormativity research. International Journal of the Sociology of Language 212: $149-179$.

Scott M (2012) WordSmith Tools version 6. Liverpool: Lexical Analysis Software.

Spender D (1980) Man Made Language. London: Routledge.

Van Dijk TA (1998) Ideology: A Multidisciplinary Approach. London: Sage.

Whittle S (1996) Gender fucking or fucking gender? Current cultural contributions to theories of gender blending. In: Ekins R, King D (eds.) Blending Genders: Social Aspects of Cross-Dressing and Sex-Changing. London: Routledge. pp: 196-214.

Wodak R, Meyer M (eds) 2001. Methods for Critical Discourse Analysis. London: Sage. 